\title{
JENSEN'S INEQUALITY FOR FUNCTIONS
}

\section{SUPERQUADRATIC ON THE COORDINATES}

\section{S. BANIĆ AND M. KLARIČIĆ BAKULA}

Abstract. Jensen's type inequalities for functions superquadratic on the coordinates are given. Obtained results are used to prove several Hölder-type inequalities.

Mathematics subject classification (2010): 26D15, 26B25.

Keywords and phrases: Functions superquadratic on the coordinates, Jensen's inequality.

\section{REFERENCES}

[1] S. Abramovich, G. Jameson, G. Sinnamon, Refining Jensen's inequality, Bull. Math. Soc. Sci. Math. Roumanie (N.S.) 47 (95) (2004), no. 1-2, 3-14.

[2] S. Abramovich, S. Banić, M. Matić, Superquadratic functions in several variables, J. Math. Anal. Appl. 327 (2007), no. 2, 1444-1460.

[3] M. Klaričić BAKUla, J. PeČARIĆ, On the Jensen's inequality for convex functions on the coordinates in a rectangle from the plane, Taiwanese J. Math. 10 (2006), no. 5, 1271-1292.

[4] Morton L. Slater, A companion inequality to Jensen's inequality, J. Approx. Theory 32 (1981), no. $2,160-166$.

[5] D. S. Mitrinović, J. E. PeČArić, A. M. Fink, Classical and new inequalities in analysis, Mathematics and its Applications (East European Series), 61, Kluwer Academic Publishers Group, Dordrecht, 1993.

[6] J. E. PeČArić, F. Proschan, Y. L. Tong, Convex functions, partial orderings, and statistical applications, Mathematics in Science and Engineering, 187, Academic Press, Inc., Boston, MA, 1992. 